\title{
Enhancing Creative Problem Solving Skills using LEGO® Mindstorm EV3 in STEM Based Learning
}

\author{
Alfiansah Sandion Prakoso ${ }^{1}$, Nurazizah ${ }^{2}$, Anti Haryanti ${ }^{3}$, Salman Al-Farizi ${ }^{4}$, Lilik \\ Hasanah $^{5}$, Irma Rahma Suwarma ${ }^{6}$ \\ \{alfisandion@outlook.com ${ }^{1}$ \}
}

Universitas Pendidikan Indonesia, Jl. Dr. Setiabudhi No. 229 Bandung 40154, Indonesia ${ }^{1,2,3,4,5,6}$

\begin{abstract}
Creative Problem Solving (CPS) is a process to solve a problem faced imaginatively and resulted in effective action. There are 4 aspects that are assessed in CPS which are fact finding, problem finding, idea finding, and solution finding. With the assumption that CPS could be trained and improved, this research aim is to investigate the enhancement of senior high school student's CPS skills after practicing STEM-based learning. The topic in this research is the concept of momentum and impulse using LEGO ${ }^{\circ}$ Mindstorm EV3 as the media. This study uses a pre-experimental method with one group pretest-posttest design. The sample of this research is 25 senior high school students in Bandung that are determined with the cluster random sampling technique. By analyzing the N-Gain, the result shows that the enhancement of CPS skill is in the middle category with $\langle\mathrm{g}\rangle$ between $0.31-0.63$.
\end{abstract}

Keywords: STEM-based learning, Creative Problem Solving, LEGO® Mindstorm EV3

\section{Introduction}

The rapid changes in our world require students to be flexible, to take the initiative and lead when necessary, and to produce something new and useful. Especially, in the 21 st century where development in science and technology is fundamentally altering the way people live, connect, communicate and transact. One of the 21 st century skills that students need to have to face these challenges is Creative Problem Solving (CPS).

Creative problem solving is the process of being sensitive to problems, deficiencies, knowledge gaps, and being able to identify difficulties, find solutions, make predictions, form hypotheses, test hypotheses, modify and repeat hypotheses so that the results could be communicated. In a simpler way, CPS is a process, method, or system to approach the problem in an imaginative way and produce an effective action [1].

CPS skill is considered to be important because of its big role in the process of decision making which requires the ability to think divergently and convergently. However, based on the preliminary study thas has been conducted in one Senior High School in Bandung shows that the students' CPS skill is still on the low category. Most of the students still found it difficult to identify the problem and finding an idea to solve it. Some writers also reported that students have a low result of CPS skills in various aspects [2],[3].

Various efforts have been made to improve CPS capabilities. One of the solutions is adopted from developed countries is through STEM-based learning (Science, Technology, Engineering, and Mathematics). STEM-based learning develops scientific inquiry and 
engineering design capabilities that are considered to contribute to the preparation of the $21 \mathrm{st}$ century workforce, one of them is CPS skills [4]. However, there are some challenges in conducting STEM-based learning in class such as, the demands of the curriculum that still needs to be fulfilled. Law of momentum conservation is viewed as a harder topic especially about proofing how the law of conservational momentum by doing an observation about a collision.

STEM-based learning can also be achieved through an activity that utilizes the LEGO® Mindstorm EV3[5]. LEGO® Mindstorm EV3 is a third edition educational robot from the LEGO ${ }^{\circledR}$ toys company that can specifically be used to train STEM skills. LEGO® EV3 Mindstorm could measure variables such as speed, distance, and mass according to the mathematical formula of momentum.

Several studies using LEGO® have been carried out including enhancing mathematical skills [6], a physical skill such as pendulum [7], doppler effects [8], free fall [9], and basic engineering processes [10]. In addition, studies using LEGO ${ }^{\circledR}$ Mindstorm have also been conducted to train creativity and teamwork [11],[12]. But not many researchers have tried to use LEGO® to assess and enhance the students' CPS.

Based on the description above we could know that CPS skill is important to be trained to the students, this study aims to enhance the students CPS skills after they go through the STEMbased learning using LEGO® Mindstorm EV3 as the media.

\section{Methods}

This study was carried out using a quantitative pre-experiment method. The design used is a one-group pretest-posttest. This design was chosen because the researchers only aimed to see the improvement of the CPS skills of the students before and after STEM-based learning, not to compare it with other learning methods. The research sample consisted of 25 high school students of class $\mathrm{X}$ in the city of Bandung which were determined using cluster random sampling technique.

The learning process includes the activity of scientific practices and engineering practices. Activities using LEGO ${ }^{\circledR}$ Mindstorm EV3 take place when the students experiencing engineering practices. The LEGO® Mindstorm EV3 software has a block programming system that allows the student to not have a high-level coding ability. The students command the LEGO® robot by combining or connecting each block using the drag and drop method, modify the variable, and then uploading it to the device. Before designing the program, the students are introduced to the interface and basic knowledge about this program. Then students design a motion simulation program that reflects the momentum conservation law.

The instruments used in this study are Creative Problem Solving test in form of essays totaling 4 items, each of which had 4 sub-questions (a,b,c, and d) so that the total was 16 items. Each question addresses a different problem topic. This question is adapted from a problem that has existed in previous studies [13]. The test scoring refers to the indicator of Torrance's creativity, namely fluency, flexibility, and originality seen in 4 aspects of problem-solving, which are fact finding (questions no. 1a, 2a, 3a and 4a), problem finding (questions no. 1b, 2b, $3 b$, and $4 b$ ), idea finding (questions no. $1 c, 2 c, 3 c$, and $4 c$ ), and solution finding (questions no. $1 d, 2 d, 3 d$, and $4 d$ ). An example of how each question scored is shown below on Table 1. 
Table 1. Example of rubric scoring.

\begin{tabular}{llllc}
\hline No. & $\begin{array}{l}\text { Creative } \\
\text { Aspect }\end{array}$ & $\begin{array}{l}\text { Problem } \\
\text { Solving } \\
\text { Aspect }\end{array}$ & \multicolumn{1}{c}{ Criteria } & Score \\
\hline 1. & $\begin{array}{l}\text { Original } \\
\text { ity }\end{array}$ & Idea Finding & $\begin{array}{l}\text { Student propose a unique idea } \\
(<5 \% \text { similarity) }\end{array}$ & 3 \\
& & $\begin{array}{l}\text { Student propose quiet different } \\
\text { idea (5-10\% similarity) } \\
\text { Student can't propose unique } \\
\text { idea (>10\% similarity) }\end{array}$ & 2 \\
\hline
\end{tabular}

The maximum score for each item is 3 and the minimum is 1. CPS skills improvement was processed from the pretest and posttest scores of students and then analyzed using N-Gain.

\section{Result and Discussion}

\section{Fact Finding}

In this study, the pretest and posttest result was categorized based on the improvement of each aspect assessed. The first aspect that will be discussed is fact finding. In this aspect, we tried to analyze students' creativity skills (from the answer sheets) in finding facts based on the context and other facts or hidden data from the problem-related situation. The result shows that in every discussed item, fluency indicator has a higher increase rather than flexibility as can be seen on Figure 1.

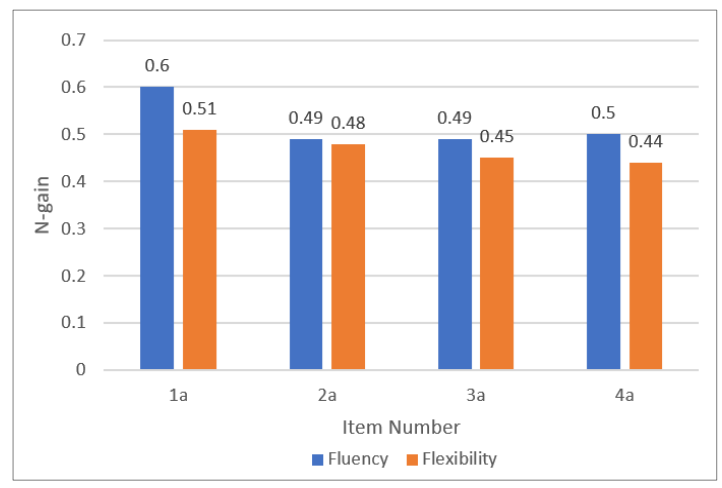

Fig. 1. Students CPS skill improvement in fact finding aspect.

In this case, we can interpret that students are more adept at finding many facts or conditions contained in the topic, rather than finding a fact then linking it to other disciplines. Overall, each student has a better fact finding skills at the posttest. For example, the lowest student score is 2 in the pretest (maximum score is 12), at the time of posttest has increased to 7 (already able to at least find 1 piece of facts for each problem given)

Problem Finding

We analyze the students' creative thinking skills in identifying the possibility of problems arises due to situations in a certain topic. The study result shows that the students are more capable of finding or identifying a problem that arose due to a situation in certain topics. We 
analyze the answer sheets at the time of the posttest, there is no more student that couldn't identify the problem in each item given. Besides that, the percentage of the students that couldn't link a problem with other discipline has been decreased from $80 \%$ to $24 \%$ at the posttest. This is probably caused by the STEM learning process that trains student's to be aware of problems both when the scientific process takes place and also when students are faced with problems while programming LEGO $^{\circledR}$ although the results of the trials are still not in accordance with their estimation. Figure 2 shows the design of the program created by students.

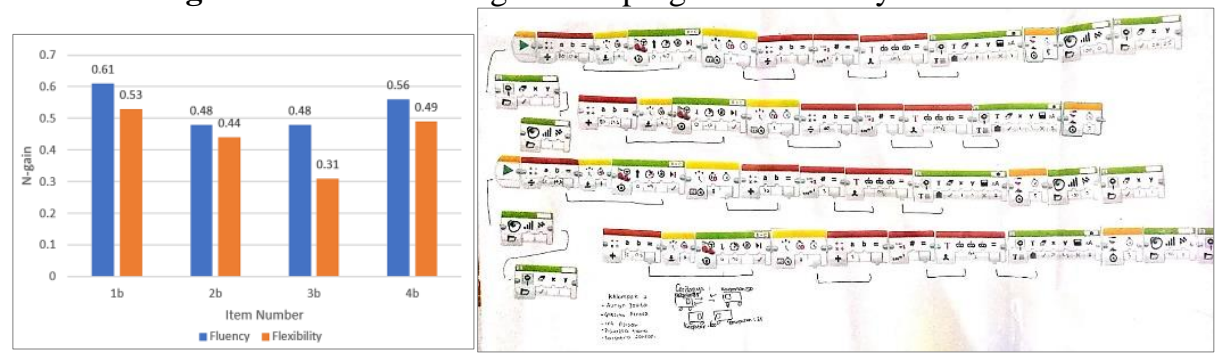

Fig. 2. (a) Students CPS skill improvement in problem finding aspect. (b) One of the student's group LEGO® program's design.

\section{Idea Finding}

In these aspects, students' creative thinking skills are analyzed by finding several ideas that could be used to solve the problem. There are 3 creativity indicators assessed in this aspect. Originality assess how unique student's idea compared to others. Figure 3 shows the improvement of students' idea finding skills in fluency, flexibility and originality.

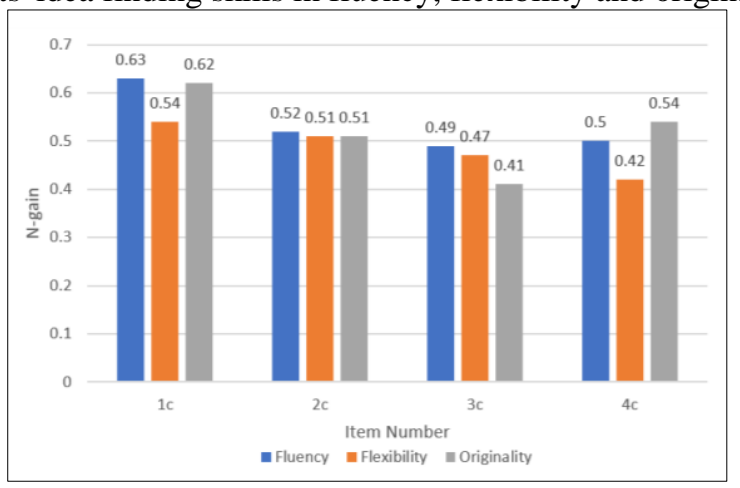

Fig. 3. Students CPS skill improvement in the idea finding aspect.

An interesting finding in this aspect is there are 5 students that couldn't resolve the problem given at all, at the time when the lesson ends they should be able at least to write one idea (even some students have more than one) that could be applied in the problem. At this point, they also able to link their idea to other disciplines. Researchers assumed that this improvement may be due to the workseet on STEM based learning given to students that often train the students to be able to find their own idea. Figure 4 shows the example of the student's worksheet. 


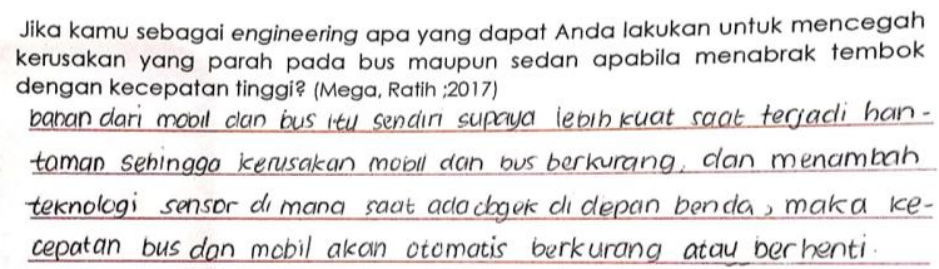

Fig. 4. Example of student's worksheet.

Solution Finding

Every idea doesn't always lead to the right solution. Therefore, in this aspect, the students' skill in choosing the most suitable idea to solve the problem is analyzed based on the ideas that have been expressed in the aspect of idea finding. The indicator of creativity that is preferred here is originality. The more students who have the same ideas with their partners, the more the level of authenticity will be reduced. Figure 5 below shows that the ability of students to find solutions also increases. This increasing is also much reflected in the answers of students who are more varied than when the pretest was taken.

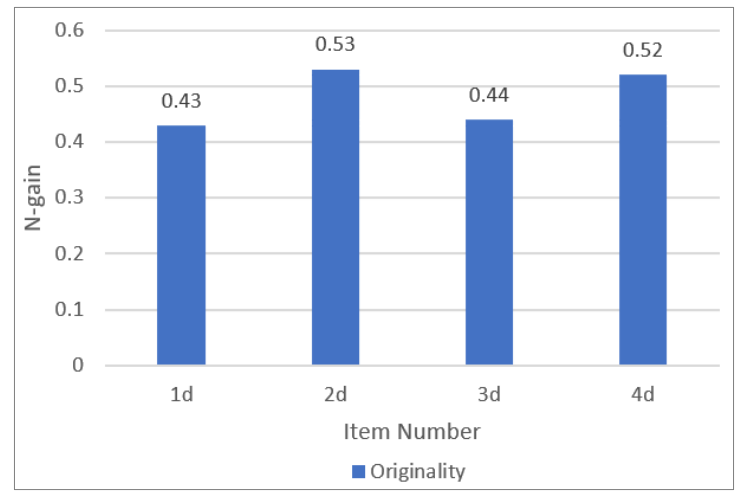

Fig. 5. Students CPS skill improvement in solution finding aspect.

\section{Conclusion}

This research shows that STEM-based learning is able to improve students' fluency, flexibility, and originality in each problem-solving skills assessed aspect, namely fact finding, problem finding, idea finding, and solution finding. Student's CPS improvements included in the medium category using the $\mathrm{N}$-gain calculation. The use of LEGO® Mindstorm EV3 as a learning media also helps students understand the concept of momentum and impulse better. The number of LEGO ${ }^{\circledR}$ robots used was not hampering the learning process even though it would be more optimal for each group to use one $\mathrm{LEGO}{ }^{\circledR}$ robot. 


\section{References}

[1] Mitchel, W.E .\& Kowalik, T.F.: Creative Problem Solving (3rd ed.). NUCEA:Genigraphics Inc. (1999)

[2] Amelia, Kiki: Penerapan Pembelajaran IPA Berbasis STEM untuk Meningkatkan Keterampilan Berpikir Kreatif dalam Memecahkan Masalah Global Warming Peserta didik SMP (Skripsi). Universitas Pendidikan Indonesia (2018)

[3] Busyairi, A.: Penerapan Strategi Pembelajaran Creative Problem Solving Berbasis Eksperimen Dalam Pembelajaran Fisika untuk Meningkatkan Kemampuan Kognitif dan Keterampilan Berpikir Kreatif dalam Pemecahan Masalah Siswa SMA pada Materi Listrik Dinamis (Tesis). Universitas Pendidikan Indonesia (2015)

[4] Sen, Ceylan \& Ay, Zeynep \& Kiray, Seyit. : STEM Skills in the 21st Century Education. (2018)

[5] V. Costa, A. Sousa, T. Cunha, C. Morais: Robotics: A Teaching Tool For STEM Education In High School. 7th International Conference on Education and New Learning Technologies (2015)

[6] Alfieri, et al.: Case Studies of a Robot-Based Game to Shape Interests and Hone Proportional Reasoning Skills. International Journal of STEM Education, 2, (4), pp. 1-10 (2015)

[7] Bobtsov, A., Alexey, et al.: Using of LEGO Mindstorms NXT Technology for Teaching of Basics of Adaptive Control Theory. International Federation of Automatic Control (IFAC) (2011)

[8] Ashdown, J. \& Doria, D.: A Robotics Based Design Activity to Teach the Doppler Effect. IEE Integrated STEM Education Conference, pp.1- 8 (2013)

[9] Ospennikov, E.: Educational Robotics as an Inovative Educational Technology. Science Direct. pp. 78-84 (2015).

[10] Marulcu \& Barnet.: Fifth Graderse Learning About Simple Machines Through Engineering Design-Based Instruction Using LEGO ${ }^{\mathrm{TM}}$ Materials. International Science Education, 43 (5) (2013)

[11] Eguchi, A.: Robo Cup Junior for promoting STEM education, 21st century skills, and technological advancement through robotics competition. Science direct. pp. 77-85 (2016)

[12] Scaradozzi, David, dkk.: Teaching robotics at the primary school: an innovative approach. Science Direct (2015)

[13] Hafifah, Ratih Mega Ayu: Pengembangan Buku Ajar Fisika Berbasis STEM Berbantuan LEGO Mindstorm EV3 untuk Meningkatkan Kemampuan Berpikir Kreatif dan Pemahaman Konsep Siswa. S2 thesis, Universitas Pendidikan Indonesia (2017) 